\title{
USE OF PLANT GROWTH REGULATORS IN FIG TREE SEEDLINGS 'ROXO DE VALINHOS'
}

\author{
USO DE REGULADORES VEGETAIS EM MUDAS DE FIGUEIRA 'ROXO DE \\ VALINHOS'
}

\author{
Jackson Mirellys Azevêdo SOUZA ${ }^{1}$; Sarita LEONEL $^{1}$; Marcelo de Souza SILVA ${ }^{\mathbf{1}}$; \\ Rafael Bibiano FERREIRA ${ }^{1}$; Rafael Augusto FERRAZ ${ }^{2}$; Joyce Helena MODESTO'; \\ Marco Antonio TECCHIO \\ 1. Department of Horticulture, São Paulo State University (UNESP), School of Agriculture, Botucatu, SP, Brazil. \\ Jackson.mirellys@ @otmail.com; 2. Federal Institute of Amazonas (IFAM), Campus Itacoatiara, Itacoatiara, AM, Brazil.
}

\begin{abstract}
The application of plant growth regulators can promote better development of the seedlings, essential for the success of fruit growing. The current study aims to evaluate the use of plant growth regulators in fig tree seedlings 'Roxo de Valinhos'. The experiment was carried out in a suspended nursery covered with plastic, using rooted cuttings of the cultivar Roxo de Valinhos. Four applications were made with a commercial product, known as Stimulate ${ }^{\circledR}$, at doses of 0, 50,100, 150, and $200 \mathrm{~mL} \mathrm{~L}^{-1}$. Using a randomized block experimental design, the study was subdivided into plots (doses X days of the last application [after 0, 7 , 14 and 21]). The following traits were evaluated: stem and root length; stem diameter; root volume; leaf number; leaf area; stem, leaf and root dry mass; specific leaf area, leaf weight ratio; leaf area ratio; and chlorophyll total. Results indicated that the product promoted greater seedlings development at a dose range from 100 to $150 \mathrm{~mL} \mathrm{~L}^{-1}$. Different dose levels did not vary according to the days after product application. Furthermore, using such technique enabled seedlings of higher quality and vigour.
\end{abstract}

KEYWORDS: Ficus carica. Auxin. Giberelin. Cytokinin. Propagation.

\section{INTRODUCTION}

The fig tree (Ficus carica L.) is considered one of the most important grown fruits in the world. Brazil is the eighth largest producer of figs, with a production of 26.9 thousand tons in 2016 (FAOSTAT, 2018). South and Southeast regions are responsible for most of the fig production in Brazil, especially São Paulo, Rio Grande do Sul and Minas Gerais, which produced 11.4, 9.8 and 4.3 thousand tons of the fruit in 2016, respectively (IBGE, 2018).

The cultivar Roxo de Valinhos is commonly used in Brazil, since it is easier adapted to drastic form of pruning, due to its rusticity, vigour and productivity compared to others (CAMPAGNOLO et al., 2010). Although fig tree has found favourable conditions for its development in Brazil, the cultivation method is quite traditional (DALASTRA et al., 2009).

Therefore, searching for the improvement in seedlings quality is necessary, but uncommon for fig trees. Seedling quality is a primary factor for fruit species, since they are perennial plants and produce over a long period of time (TOMAZ et al., 2015). For figs seedlings production, cuttings is the most common propagation technique, that is, woody stem cuttings are obtained within winter pruning
(SOUSA et al., 2013), independent of cuttings conditions. The use of cuttings with low carbohydrate reserves or even plant hormones develops plants with low vigour compared to cuttings collected at ideal times. Several practices can be used to improve the quality in seedlings production, such as plant growth regulators that are quite common around the world (TECCHIO et al., 2015).

Plant growth regulators are synthetic substances that act in small concentrations; thus, presenting similar effects of plant hormones; they are natural substances synthesized in low concentrations that act on various plants organs, controlling their growth and development (TAIZ et al., 2017). Besides plant growth regulators, commercial products that are composed by the association of these compounds are also found, they are constituted of one or more plant growth regulators with different biochemical compounds. Promising results are found in the literature using such product.

By using Stimulate ${ }^{\circledR}$ (cytokinins + auxins + gibberellins) and substrates to propagate blackberry, Dias et al. (2012) verified no effect in the cuttings root, but great development in the stems. Besides that, Silva et al. (2014) observed a larger colon 
diameter in watermelon seedlings compared to untreated seedlings by using Stimulate ${ }^{\circledR}$. Additionally, Tecchio et al. (2015) reported higher height, leaf number, root length and diameter in Nagami kumquat seedlings treated with the same product. Likewise, Souza et al. (2016) obtained better seedlings vegetative performance when propagated litchi by air layering with Stimulate ${ }^{\circledR}$.

Moreover, fig trees are still restricted to synthetic auxins for rooting within seedlings production, since plant growth regulator becomes expendable at this stage. Although there has not been many studies on the use of plant growth regulators for developing better seedlings in cutting propagation. Even though pruning is not often held at ideal times, seedlings develop, but they do not reach the highest potential. Therefore, the use of plant growth regulators may enable the production of high quality fig tree seedlings. Given all the above, the current study aims to evaluate the implications of using plant growth regulators in seedling production of 'Roxo de Valinhos' fig tree.

\section{MATERIAL AND METHODS}

The experiment was carried out in a suspended nursery from August to December 2015. Plant nursery was located at Botucatu, which is located in the central-south region of the state of São Paulo $\left(48^{\circ} 25^{\prime} \mathrm{W}, 22^{\circ} 5^{\prime} \mathrm{S}\right)$, with a Cwa climate, according to Köppen classification.

In August, 'Roxo de Valinhos' branches were collected from orchard in São Manuel, São Paulo, which belongs to laboratory. After collecting, branches were wrapped in paper bags, moistened and conditioned in thermal refractory. Then, cuttings were prepared from these branches, standardized with $20 \mathrm{~cm}$ in length (approximately 5 buds) and average diameter of $7 \mathrm{~mm}$, by means of a straight cut at the apex (i.e. one centimetre above the first bud) and a bevel cut at the base of the cutting (i.e. one centimetre below the last bud). Afterwards, cuttings were buried $1 / 3$ of its length in $290 \mathrm{~cm}^{3}$ tubes containing sand $\left(\leq 30^{\circ} \mathrm{C}\right)$ and relative air humidity ( $>80 \%$ ), being monitored by intermittent irrigation system by nebulisation. The flow rate from hose to nozzle was $7 \mathrm{~L} \mathrm{~h}^{-1}$, such system was automatically triggered by electromagnetic panel for 10 seconds every 15 minutes from $9 \mathrm{am}$ to $4 \mathrm{pm}$.

During 90 days, cuttings were kept in a greenhouse for rooting, later transplanted in $350 \mathrm{ml}$ polyethylene bags filled with Topstrato ${ }^{\circledR}$ substrate (HT Hortaliças) and transported to suspended linear nursery covered with plastic. Microsprinkler irrigation system was used, with nozzles flow of 200 $\mathrm{L} \mathrm{h}^{-1}$ that was automatically activated for 20 seconds every 30 minutes from $9 \mathrm{am}$ to $4 \mathrm{pm}$ by electromagnetic panel. During seedlings development, lateral buds developed, which left one shoot per cutting.

After 30 days of transplanting the seedlings, four applications were made with the commercial product, known as Stimulate $^{\circledR}$, in seven-day intervals. The product is composed of three plant growth regulators: $0.009 \%$ kinetin (cytokinins - Ck), $0.005 \%$ gibberellic acid (gibberellins - GA) and $0.005 \%$ indolylbutyric acid (auxins - Ax), manufactured by Stoller do Brasil Ltda. The applications were carried out at doses of 0, 50, 100, 150 , and $200 \mathrm{~mL} \mathrm{~L}^{-1}$, with $10 \mathrm{~L}$ backpack sprayer nozzles, flow rate of $600 \mathrm{~mL} / \mathrm{min}^{-1}$. The product was diluted with water; about $20 \mathrm{~mL}$ of solution was applied per seedling to cover all shoot.

The seedlings were evaluated at $0,7,14$ and 21 days after application of the plant growth regulators by means of the following characteristics: stem and root length, measured with a graduated ruler; stem diameter, using digital calliper; root volume; number of leaves; leaf area; stem, leaf and root dry mass; specific leaf area, leaf weight ratio and leaf area ratio, according to the methodology proposed by Benincasa (2003); and chlorophyll $a, b$ and total contents. For leaf area measurement, it was used the methodology proposed by Souza et al. (2014), in which three leaf lengths were measured with a graduated ruler by means of whether leaf area is obtained in $\mathrm{cm}^{2}$, to obtain the plant's leaf area, add the area of all leaves.

For dry mass, all material was packed in paper bags and kept in oven with forced air circulation at a temperature of $65^{\circ} \mathrm{C}$ until reaching constant mass. Root volume was measured in 100 $\mathrm{mL}$ graduated beaker, roots were immersed in a beaker containing a known volume of water, volume was recorded in millilitres $(\mathrm{mL})$ of displaced water, then these values were converted into cubic centimetres.

For chlorophyll $a, b$ and total, four seedlings of each replicate were used. The methodology used was that of Arnon (1949). Chlorophyll extraction was carried out in $10 \mathrm{~mL}$ of $80 \%$ acetone using approximately four centimetres of leaf fresh mass, placed in a $25 \mathrm{~mL}$ beaker, coated with aluminium foil and stored under refrigeration for 48 hours. Afterwards, the extracts of chlorophyll were transferred to a $3 \mathrm{~mL}$ glass cuvette; then absorbance reading was performed at wavelengths of $645 \mathrm{~nm}$ and $663 \mathrm{~nm}$ (nanometres). 
The experimental design was subdivided in plots that corresponded to the doses of the product composed by plant growth regulators $(0,50,100$, 150 , and $200 \mathrm{~mL} \mathrm{~L}^{-1}$ ) and subplots consisted of the four evaluation periods (after 0, 7, 14 and 21 days of the last application). Thus, four blocks of 20 plants per dose of the product, which were divided into four subplots that contained 5 plants each. The data obtained were submitted to analysis of variance and, when significant, regression analysis was performed for Stimulate ${ }^{\circledR}$ doses and evaluation periods at $1(\mathrm{p}$ $<0,01)$ and $5 \%(p>0,05)$ of probability, using the Computational Program System for Analysis of Variance - SISVAR (FERREIRA, 2011).

\section{RESULTS AND DISCUSSION}

Results indicated no significant interaction between product doses and number of days after the last application to none of the evaluated characteristics. However, results were significant whether factors were evaluated separately, such as 'doses' for stem length and diameter, main root length, root volume, leaf number, leaf area, leaf dry mass, stem dry mass and specific leaf area. In addition to aforementioned traits, 'days after application' also presented significant results for leaf weight ratio, leaf area ratio and chlorophyll $a$ and total chlorophyll content (Tables 1).

Table 1. F test, coefficients of variation (CV), mean stem length (SL), stem diameter (SD), root length (RL), root volume (RV), leaf number (LN), leaf area (LA), leaf dry mass (LDM), stem dry mass (SDM), root dry mass (RDM), specific leaf area (SLA), leaf weight ratio (LWR), leaf area ratio (LAR) and chlorophyll a (CA), b (CB) and total (CT) in seedlings of 'Roxo de Valinhos' fig tree. Botucatu, state of São Paulo, 2016.

\begin{tabular}{|c|c|c|c|c|c|c|c|c|}
\hline FV & $\begin{array}{l}\text { SL } \\
(\mathrm{mm})\end{array}$ & $\begin{array}{l}\text { SD } \\
(\mathrm{mm})\end{array}$ & $\begin{array}{l}\mathrm{RL} \\
(\mathrm{cm})\end{array}$ & $\begin{array}{l}\mathrm{RV} \\
\left(\mathrm{cm}^{3}\right)\end{array}$ & LN & $\begin{array}{l}\text { LA } \\
\left(\mathrm{cm}^{2}\right)\end{array}$ & $\begin{array}{l}\text { LDM } \\
(\mathrm{g})\end{array}$ & $\begin{array}{l}\text { SDM } \\
(g)\end{array}$ \\
\hline Blocks & $4.5^{*}$ & $1.3^{\mathrm{ns}}$ & $0.8^{\text {ns }}$ & $1.9^{\mathrm{ns}}$ & $2.2^{\mathrm{ns}}$ & $4.4^{*}$ & $0.4^{\mathrm{ns}}$ & $1.3^{\mathrm{ns}}$ \\
\hline Doses (A) & $4.7^{*}$ & $6.0^{* *}$ & $7.1^{* * *}$ & $6.7^{\text {*** }}$ & $2.5^{*}$ & $7.9^{* *}$ & $3.2^{*}$ & $3.1^{*}$ \\
\hline Days (B) & $3.8^{*}$ & $7.0^{* *}$ & $2.8^{\mathrm{ns}}$ & $7.6^{* *}$ & $28.2^{* *}$ & $7.5^{* *}$ & $53.2^{* * *}$ & $2.8^{*}$ \\
\hline $\mathrm{A} \times \mathrm{B}$ & $0.8^{\mathrm{ns}}$ & $1.9^{\mathrm{ns}}$ & $1.9^{\mathrm{ns}}$ & $0.9^{\mathrm{ns}}$ & $1.4^{\mathrm{ns}}$ & $1.5^{\mathrm{ns}}$ & $1.1^{\mathrm{ns}}$ & $0.9^{\text {ns }}$ \\
\hline CVA (\%) & 34.2 & 8.8 & 13.1 & 21.4 & 17.9 & 22.3 & 29.6 & 34.1 \\
\hline CVB (\%) & 43.0 & 10.3 & 18.1 & 27.8 & 15.6 & 39.5 & 30.0 & 38.5 \\
\hline Mean & 15.4 & 6.0 & 34.7 & 6.7 & 6.3 & 225.5 & 1.1 & 0.9 \\
\hline FV & $\begin{array}{l}\text { RDM } \\
\text { (g) }\end{array}$ & $\begin{array}{l}\text { SLA } \\
\left(\mathrm{cm}^{2} \mathrm{~g}^{-1}\right)\end{array}$ & $\begin{array}{l}\text { LWR } \\
\left(\mathrm{g} \mathrm{g}^{-1}\right)\end{array}$ & $\begin{array}{l}\text { LAR } \\
\left(\mathrm{cm}^{2} \mathrm{~g}^{-1}\right)\end{array}$ & $\begin{array}{l}\text { CA } \\
\left(\mathrm{mg} \mathrm{m}^{-2}\right)\end{array}$ & $\begin{array}{l}\mathrm{CB} \\
\left(\mathrm{mg} \mathrm{m}^{-2}\right)\end{array}$ & \multicolumn{2}{|c|}{$\begin{array}{l}\mathrm{CT} \\
\left(\mathrm{mg} \mathrm{m}^{-2}\right)\end{array}$} \\
\hline Blocks & $1.4^{\mathrm{ns}}$ & $1.1^{\mathrm{ns}}$ & $2.1^{\mathrm{ns}}$ & $6.0^{\mathrm{ns}}$ & $0.4^{\mathrm{ns}}$ & $1.7^{\mathrm{ns}}$ & \multicolumn{2}{|c|}{$2.4^{\mathrm{ns}}$} \\
\hline Doses (A) & $2.6^{\mathrm{ns}}$ & $1.8^{*}$ & $0.2^{\mathrm{ns}}$ & $1.8^{\mathrm{ns}}$ & $0.3^{\mathrm{ns}}$ & $1.6^{\mathrm{ns}}$ & \multicolumn{2}{|c|}{$2.0^{\mathrm{ns}}$} \\
\hline Days (B) & $0.4^{\mathrm{ns}}$ & $14.4^{* *}$ & $33.6^{* *}$ & $2.5^{*}$ & $16.1^{* *}$ & $2.0^{\mathrm{ns}}$ & \multicolumn{2}{|c|}{$5.4^{*}$} \\
\hline $\mathrm{A} \times \mathrm{B}$ & $0,7^{\mathrm{ns}}$ & $0.8^{\mathrm{ns}}$ & $1.0^{\mathrm{ns}}$ & $0.8^{\mathrm{ns}}$ & $1.9^{\mathrm{ns}}$ & $0.8^{\mathrm{ns}}$ & \multicolumn{2}{|c|}{$0.6^{\mathrm{ns}}$} \\
\hline CVA (\%) & 79.4 & 28.8 & 14.4 & 23.5 & 35.8 & 97.5 & \multicolumn{2}{|c|}{40.8} \\
\hline CVB (\%) & 93.4 & 38.8 & 17.2 & 39.5 & 20.5 & 109.0 & \multicolumn{2}{|c|}{46.3} \\
\hline Mean & 1.4 & 236.1 & 0.54 & 119.7 & 4.0 & 2.6 & \multicolumn{2}{|c|}{6.6} \\
\hline
\end{tabular}

${ }^{\mathrm{ns}}$ not significant; $* \mathrm{p}<0,05, * * \mathrm{p}<0,01$

Stem length was adjusted by a quadratic function of the estimated dose of $102.9 \mathrm{~mL} \mathrm{~L}^{-1}$, from which the values decreased. Likewise, the mean stem diameter was also adjusted by a quadratic increase of the dose of $113.3 \mathrm{~mL} \mathrm{~L}^{-1}$ (Figure 1A, 1B). The decrease in means observed from the maximum point may be related to the phytotoxic effect of higher doses.

Considering the estimated doses mentioned above, the increase in mean length and diameter of stems was of 43.8 and $14.1 \%$, respectively. Similarly, Ferraz et al. (2014) also observed that Stimulate ${ }^{\circledR}$ promoted a quadratic growth in the means of seedling height and diameter of 'Roxinho do Kênia' passion fruit. Dantas et al. (2012) and
Tecchio et al. (2015) reported an increase in plant height, but not in diameter of tamarind and Nagami kumquat seedlings, respectively.

The increase in mean diameter and height can be explained by the joint action of plant growth regulators, since cellular elongation is the result of auxins and gibberellins action, whereas cellular division is mainly regulated by auxins and cytokinins. These plant growth regulators are still involved with secondary plant growth, with auxins being involved in the development of secondary xylem, gibberellins with secondary phloem, and cytokinins with exchange activity (TAIZ et al., 2017). 
Root length and root volume were also adjusted by a quadratic function of the estimated doses of 142.2 and $98.0 \mathrm{~mL} \mathrm{~L}^{-1}$, respectively. Such result corresponded to $17.6 \%$ increase in root length and $33.1 \%$ in root volume compared to untreated plants (Figure 1C, 1D). Similarly, Tecchio et al. (2015) obtained higher mean in root lengths of
Nagami kumquat seedlings by applying Stimulate ${ }^{\circledR}$. Also, Ferraz et al. (2014) verified higher mean in seedlings length of 'Roxinho do Kênia' passion fruit from seeds treated with the same product. But Silva et al. (2014) observed no effect on root length of watermelon
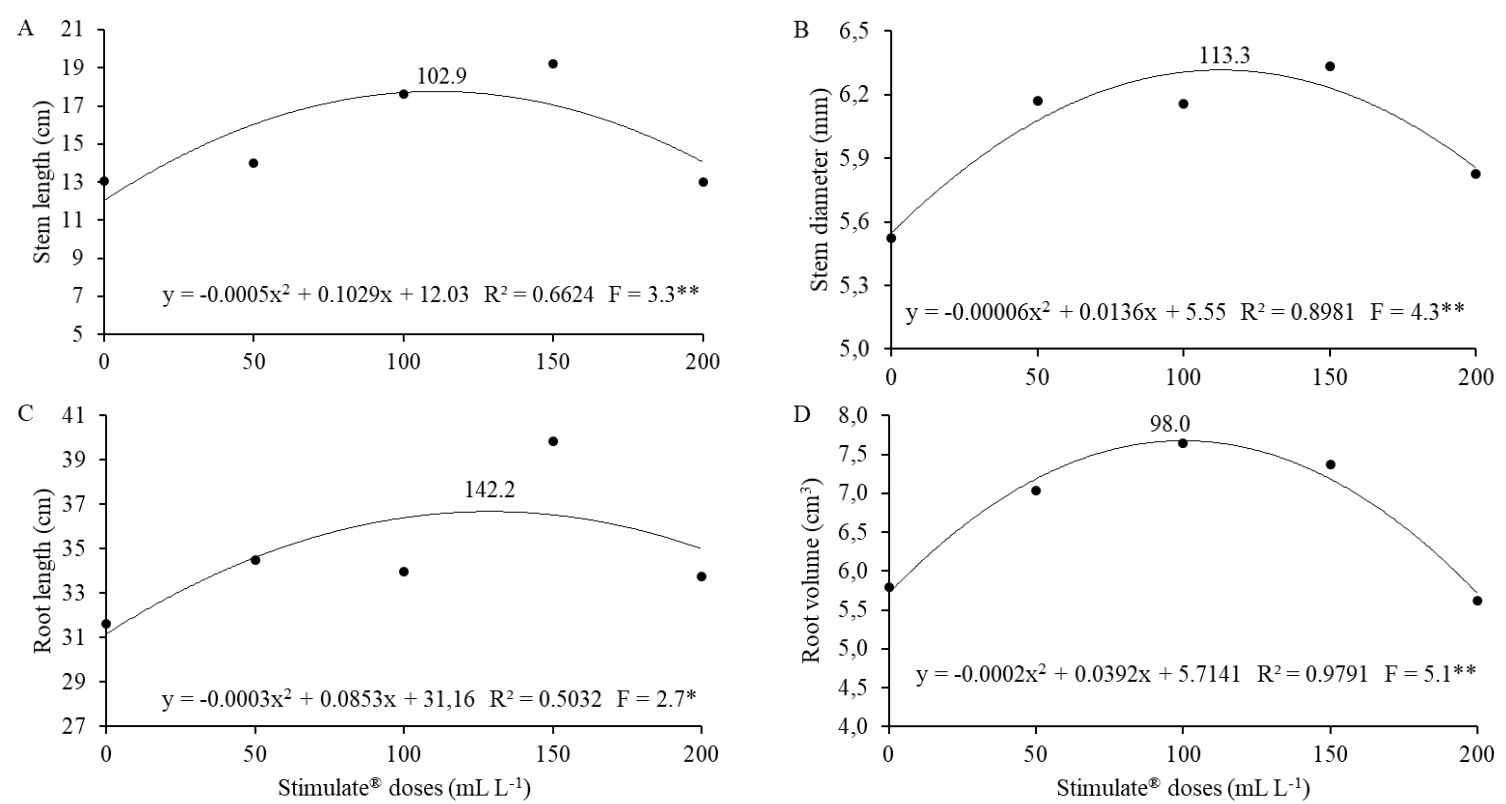

Figure 1. Stem length (A) and diameter (B), root length (C) and volume (D), in seedlings of 'Roxo de Valinhos' fig tree, as a function of the doses of plant growth regulators. Botucatu, state of São Paulo, 2016.

The highest values of length and volume may be related mainly to the presence of auxins that promotes not only greater length, but also thinner and more numerous roots, a trait that helps plants survive due to the better water absorption (DAS; PRASAD, 2014). Within fruit trees production, it is desirable using plant growth regulators that promote a greater root growth (TECCHIO et al., 2015); since greater shoot are growth to the detriment of root system and compromises seedlings adaptation in field. Results indicated a balance between the growth of shoot and root.

The highest mean in leaf number and area were reached at the estimated doses of 117.5 and $98.2 \mathrm{ml} \mathrm{L}^{-1}$, respectively. From these doses, there was a decrease in the means, indicating that doses above this limit are phytotoxic to seedlings (Figure 2A, 2B). In plants, hormonal balance associated with plant growth regulators helps to increase these traits, but the result of physiological action of cytokinins is known to promote leaf expansion.

Tecchio et al. (2015) observed that the product doubled the leaf number of Nagami kumquat seedlings at $200 \mathrm{~mL} \mathrm{~L}^{-1}$ after 21 days of application. However, Silva et al. (2014) observe no significant effect on leaf number in watermelon seedlings. It is worth noting that the different results found in the literature can be related not only to the dose used, but also to the application method; different species and environmental conditions.

Regarding to specific leaf area, the means dropped linearly with increasing doses of the product (Figure 2C). This characteristic is related to leaf area surface with leaf specific weigh, in which the surface constitutes a morphological component and weight is an anatomical component, since the latter correlates with the number and/or size of leaf mesophyll cells (BENINCASA, 2003). The specific leaf area can be used to indicate leaf thickness, for which larger values correspond to larger area per unit weight, i.e. less thick leaves, and the opposite is also true. Therefore, it can be said that the use of Stimulate ${ }^{\circledR}$ promoted thicker leaves, considering the lower values for specific leaf area.

In most cases, the highest values of specific leaf area are correlated to the highest number of leaves due to self-shading, as plants tend to prioritize the increase in leaf area instead of leaf 
density, but this was not observed in the current study. In addition to larger leaf area and greater number of leaves, the plants treated with the product also presented a smaller specific leaf area. This result is related to the fact that plant growth regulators promote not only the increase in leaf area, but also dry mass (TAIZ et al., 2017). It is also worth noting that thicker leaves are more resistant to possible damages caused by high luminosity, as the excessive water loss by perspiration (POORTER; GARNIER, 2007).

Dry mass of leaves and stems were adjusted by quadratic function of the estimated doses of
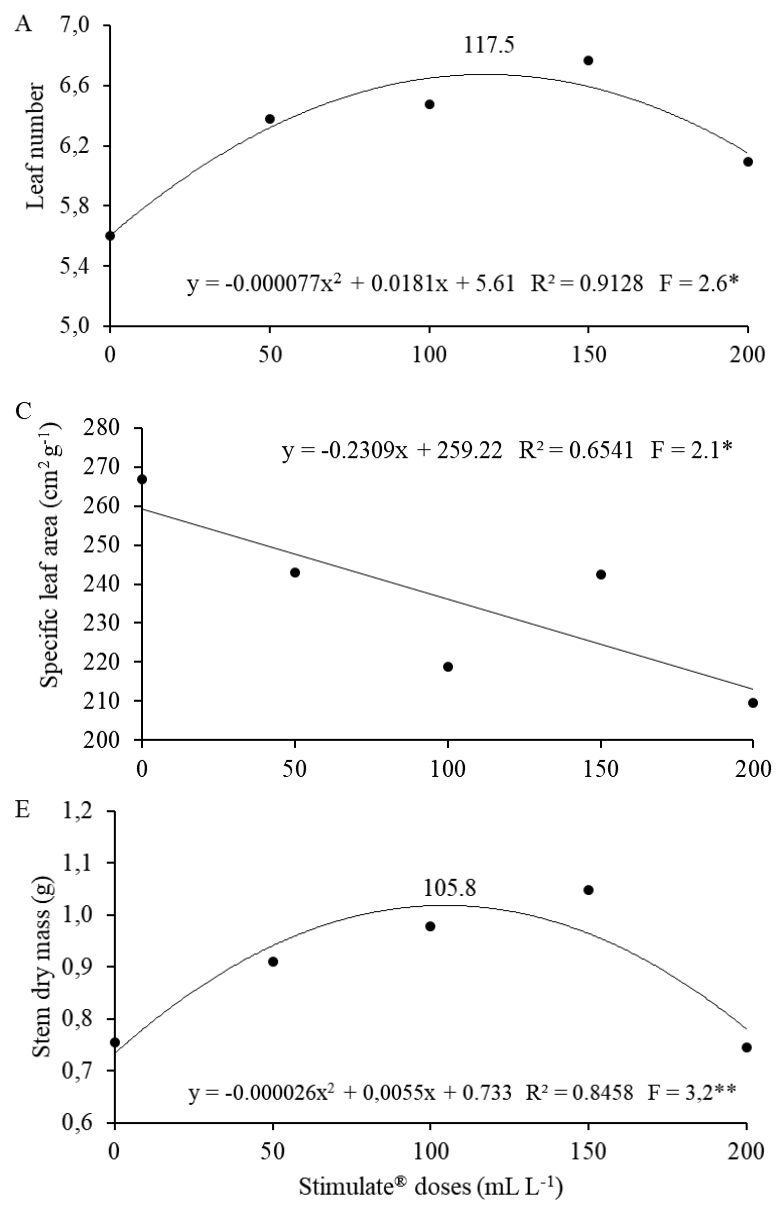

107.7 and $105.8 \mathrm{~mL} \mathrm{~L}^{-1}$, respectively (Figure 2D, $2 \mathrm{E})$. The use of higher doses than those decreased the means in these traits, again evidencing the product phytotoxic effect. Using lower doses (6.0, 12.0, 18.0 and $24.0 \mathrm{~mL} \mathrm{~L}^{-1}$ ), Dantas et al. (2012) observed a positive linear effect of Stimulate $^{\circledR}$, regarding dry mass of stems and roots. The application of plant growth regulators above adequate levels may result in inhibition of plant organism growth, whereas they may not have any effect at very low doses (TAIZ et al., 2017).
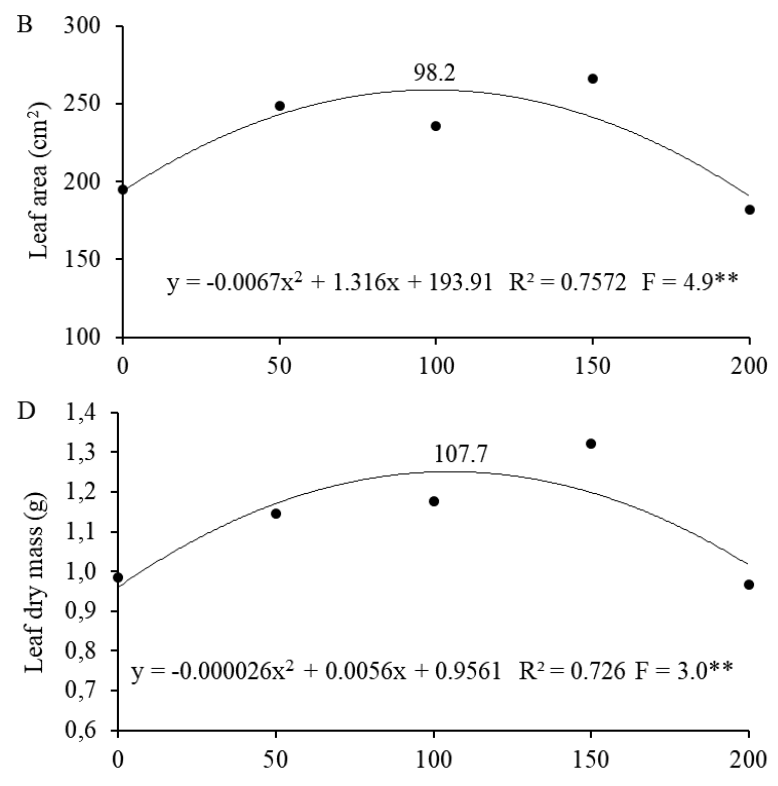

Figure 2. Leaf number (A) and area (B), specific leaf area (C) and dry mass of leaf (D) and stem (E) in seedlings of 'Roxo de Valinhos' fig tree, as a function of the doses of plant growth regulators. Botucatu, state of São Paulo, 2016.

Plant growth regulators promote an increase in root dry mass due to the increase in root number and root length (DAS; PRASAD, 2014). However, there was no increase in root dry mass in the current study. Other authors also did not find a significant effect on root dry mass using combined plant growth regulators (SILVA et al., 2014; TECCHIO et al., 2015).
Cytokinins is one of the plant hormones responsible for maintaining chlorophyll content and prevents its degradation (TAIZ et al., 2017). Although it is found in Stimulate ${ }^{\circledR}$, there was no significant effect of the product doses on the mean values of chlorophyll $a, b$ and total. Using similar doses, Tecchio et al. (2015) also found no effect of this product on the relative index of chlorophyll in Nagami kumgat seedlings. Again, it is worth 
mentioning that different doses, application methods and species were used.

There was no interaction between Stimulate $^{\circledR}$ doses and the number of days after the last application; the factor 'days after application' was significant for almost all traits, in spite of root length, root dry mass and chlorophyll $b$, such result was expected since it is a plant's natural development over the time, regardless of the product application.

A positive linear effect was observed in stem length and root volume with higher means
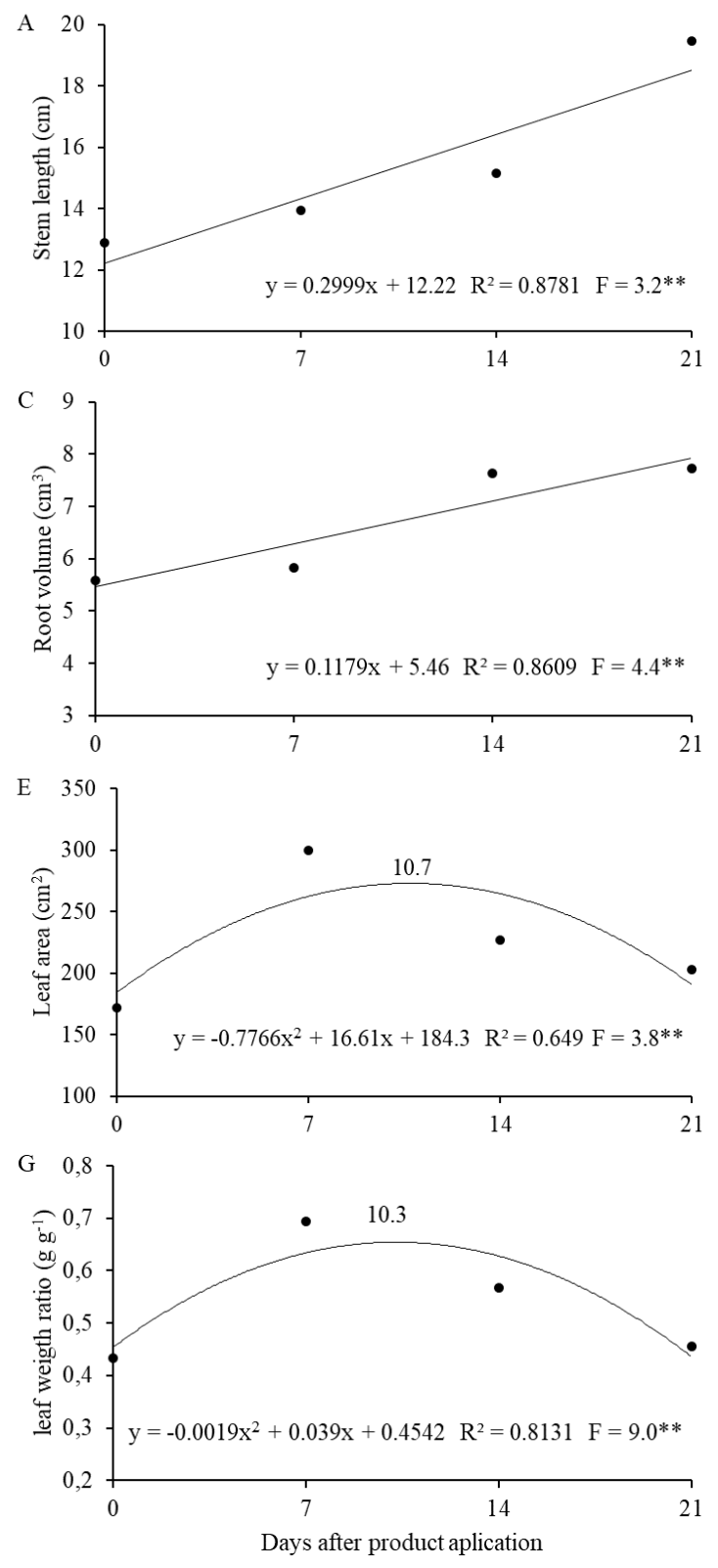

Figure 3. Stem length (A) and diameter (B), root volume (C), Leaf number (D) and area (E), specific leaf area $(\mathrm{F})$, leaf weight ratio $(\mathrm{G})$ and leaf area ratio $(\mathrm{H})$ in seedlings of 'Roxo de Valinhos' fig tree, as a function of days after product application.

Despite aforementioned traits, leaf number, leaf area and stem diameter were adjusted by after 21 days of product application, i.e. $19.48 \mathrm{~cm}$ and $7.73 \mathrm{~cm}^{3}$, respectively (Figure 3A, 3C). These traits are important, since greater length is related to vigour. Greater root volume is fundamental to seedlings success after being transplanted in field, as it is directly linked to plants survival rate. In the current study, the linear increase in root volume can be attributed to the higher water content inside the roots, as there was no significant effect of days on the length and root dry mass.
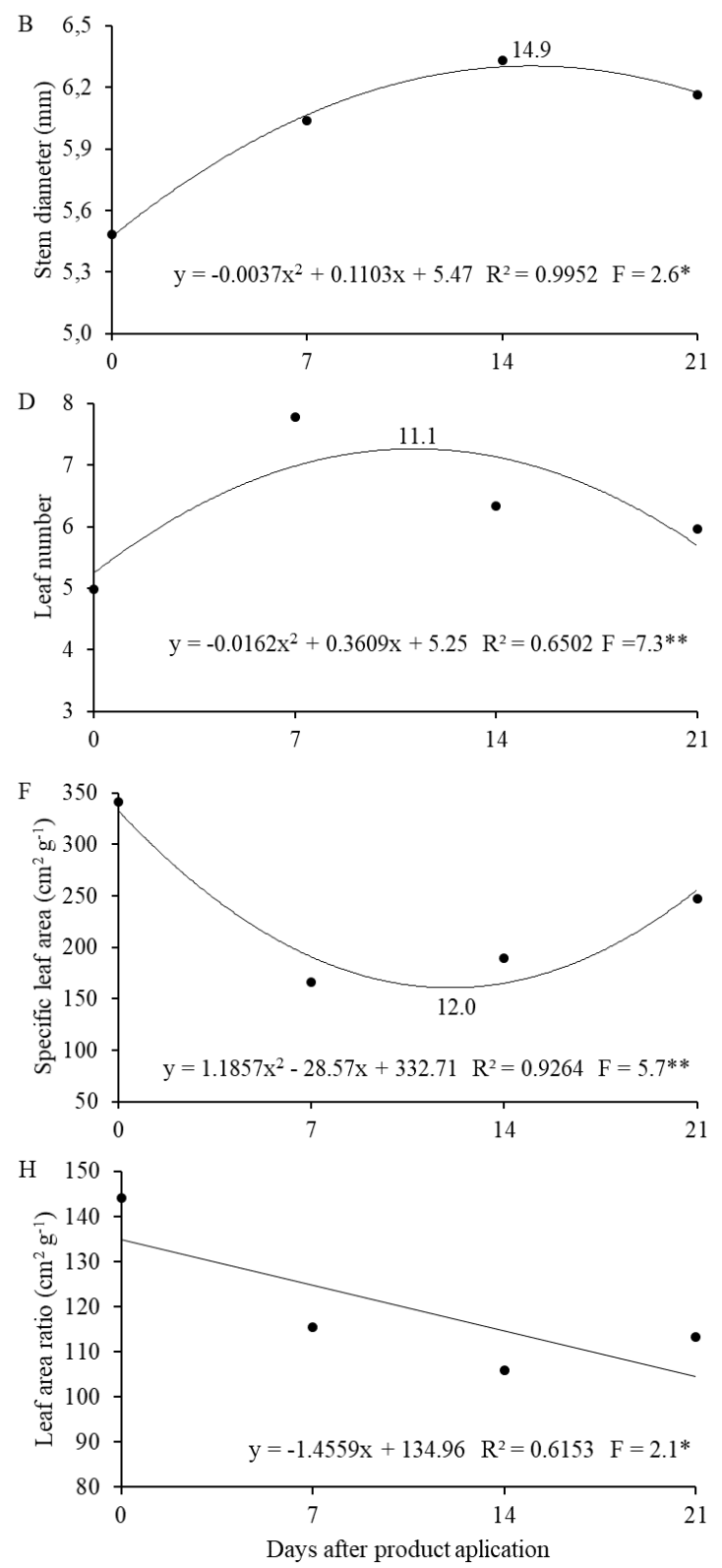
respectively (Figure 3B, 3D, 3E). From them, there was a decrease in the means. Regarding the leaf number and leaf area, this result can be attributed to leaf fall, whereas lower means of stem diameter may be related to the greater length growth, thus detrimental to diameter growth. Alike stem length, diameter is also connected to the plant vigour; while leaf number and leaf area are directly related to the plant's photosynthetic capacity.

For specific leaf area, it was noticed a quadratic decreased in means as days advanced, with a lower average after 12 days. Conversely, leaf weight ratio was adjusted by quadratic function of time up to 10.3 days (Figure 3F, 3G). The lower averages of specific leaf area as a function of time is a result of increased leaf density, in addition to a larger leaf area; there was also an expressive increase in dry mass.

However, the quadratic increase in leaf weight ratio indicates that up to 10.3 days after application, leaves exported less dry mass to other organs, prioritizing their own development, since it is obtained between leaf weight and total plant weight, expressing that dry mass fraction not exported from leaves to other plant organs. At that point, the decrease indicates that they started to
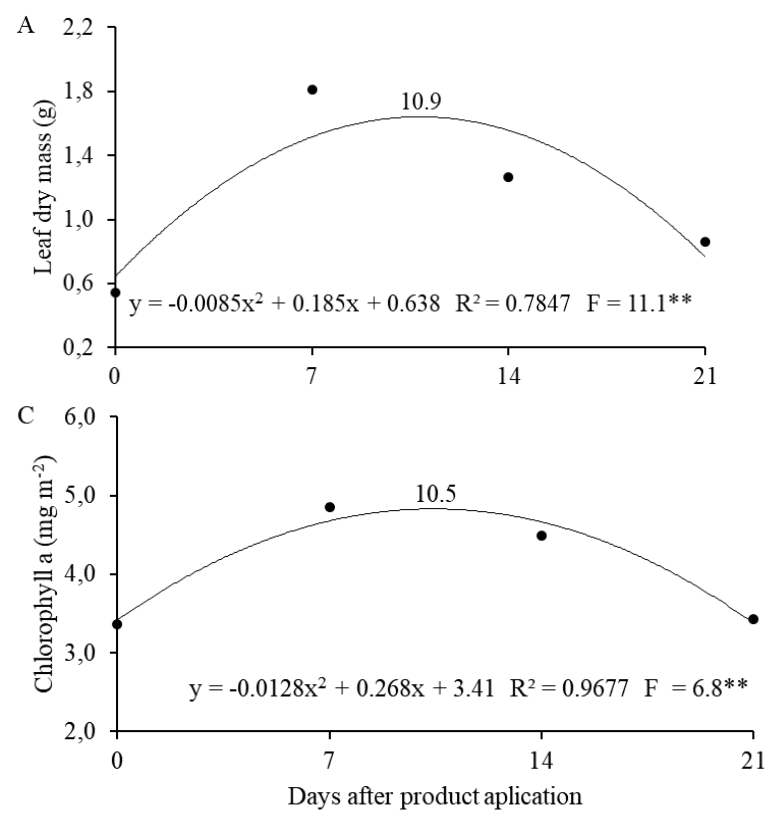

export more dry mass to other parts, explaining the linear increase in stem length as a function of time.

Leaf area ratio was obtained from specific leaf area and leaf weight ratio, the means decreased linearly up to 21 days after product application (Figure 3H). This trait corresponds to the leaf area that is used by the plant to produce one gram of dry matter, while its values decreased in plants growth, i.e. the more increase in the number of leaves and the leaf area, the more increase in self-shading; consequently, decreasing in useful leaf area for photosynthesis (BENINCASA, 2003); thus explaining lower averages in the experiment after 21 days.

The means of leaf dry mass were adjusted by quadratic function of evaluated days, being able to attribute low means to the maximum point and leaf fall. Stem dry mass increased linearly, with higher values observed after 21 days (Figure 4A, 4B). The production of dry mass by the plant has been used as a relevant factor to evaluate the quality of seedlings; however, there is the inconvenience of plant's total destruction for its measurement, making it unfeasible in many nurseries (ARRIEL et al., 2006).
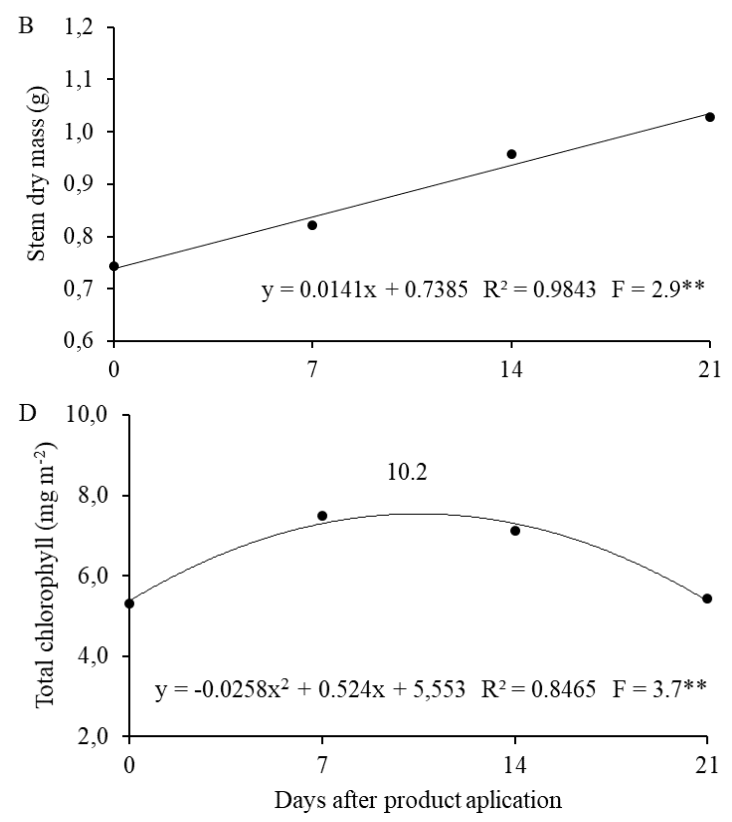

Figure 4. Leaf (a) and stem (b) dry mass and chlorophyll a (c) and total (D) in seedlings of 'Roxo de Valinhos' fig tree, as a function of the days after product application. Botucatu, state of São Paulo, 2016.

Chlorophyll $a$ and total were adjusted by a quadratic function of days, with higher means obtained after 10.5 and 10.2 days, respectively (Figure 4C, 4D). The reduction of chlorophyll content can be attributed to the greater age of the leaves, which could already be in a state of senescence, since there was no increase in the number of leaves after 11.1 days, inferring that the leaves evaluated after this point had expanded longer than those assessed in the first two assessments 
The measurement of chlorophyll content reflects leaf quality as a result of higher photosynthetic rate, which is directly related to plant growth. In addition, chlorophyll content can be used as indicative of $\mathrm{N}$ amounts in leaves, since $\mathrm{N}$ is a constituent of chlorophyll molecules and, $50-70 \%$ of $\mathrm{N}$ in leaves is associated with chloroplasts (CHAPMAN; BARRETO, 1997).

\section{CONCLUSIONS}

The application of a product composed of auxins, gibberellins and cytokinins at $100-150 \mathrm{~mL}$
$\mathrm{L}^{-1}$ promoted greater seedlings development of 'Roxo de Valinhos' fig tree.

The effect of the different doses did not vary according to the days after product application.

\section{ACKNOWLEDGMENTS}

To the National Council for Scientific and Technological Development (CNPq) to scholarship granted for the doctor's degree studies of the first author (\#140429/2014-2).

RESUMO: A aplicação de reguladores vegetais pode configurar uma técnica viável para promoção do melhor desenvolvimento das mudas, imprescindível para o sucesso da fruticultura. Deste modo, objetivou-se avaliar o uso de reguladores vegetais na produção de mudas da figueira 'Roxo de Valinhos'. O experimento foi realizado em viveiro suspenso com cobertura plástica, utilizando-se estacas enraizadas da cultivar Roxo de Valinhos. Foram realizadas quatro aplicações com o produto comercial Stimulate ${ }^{\circledR}$ nas concentrações de 0, 50, 100,150 , e $200 \mathrm{~mL} \mathrm{~L}^{-1}$. Utilizou-se o delineamento experimental em blocos casualizados com parcelas subdivididas [concentrações X épocas de avaliação (após 0, 7, 14 e 21 dias da última aplicação)]. Avaliou-se: comprimento do ramo e da maior raiz; diâmetro do ramo; volume de raízes; número de folhas e área foliar; massa seca de folhas, ramos e raízes; área específica foliar, razão de peso foliar e razão da área foliar; e teores de clorofila total. $\mathrm{O}$ uso do produto, nas concentrações de 100 a $150 \mathrm{~mL} \mathrm{~L}^{-1}$, promoveu maior desenvolvimento das mudas. $\mathrm{O}$ efeito das diferentes doses não variou em função dos dias após aplicação do produto. $\mathrm{O}$ uso de tal técnica permite a obtenção de mudas de maior qualidade e vigor.

PALAVRAS-CHAVE: Ficus carica. Auxina. Giberelina. Citocinina. Propagação.

\section{REFERENCES}

ARNON, D. I. Copper enzymes in isolated choroplasts: Polyphenoloxidase in Beta Vulgaris. Plant Physiology, Maryland, v. 24, n. 1, p. 1-15, 1949. https://doi.org/10.1104/pp.24.1.1

ARRIEL, E. F.; PAULA, R. C.; RODRIGUES, T. J. D.; BAKKE, O. A.; ARRIEL, N. H. C. Genetic divergence among progenies of Cnidoscolus phyllacanthus, submitted to three watering regimes. Científica, Jaboticabal, v. 34, n. 2, p. 229-237, 2006.

BENINCASA, M. M. P. Análise de crescimento de plantas: noções básicas. Jaboticabal: FUNEP, 2003. 41p.

CHAPMAN, S. C.; BARRETO, H. J. Using a chlorophyll meter to estimate specific leaf nitrogen of tropical maize during vegetative growth. Agronomy Journal, Madison, v. 89, n. 4, p. 557-562, 1997.

https://doi.org/10.2134/agronj1997.00021962008900040004x

CAMPAGNOLO, M. A.; PIO, R.; DALASTRA, I. M.; CHAGAS, E. A.; GUIMARAES, V. F.; DALASTRA, G. M. Sistema desponte na produção de figos verdes Roxo de Valinhos. Ciência Rural, Santa Maria, v. 40, p. 25-29, 2010. https://doi.org/10.1590/S0103-84782009005000219

DALASTRA, I. M.; PIO, R.; CAMPAGNOLO, M. A.; DALASTRA, G. M. CHAGAS, E. A.; GUIMARÃES, V.F. Pruning time in the production of 'Roxo de Valinhos' green fig in organic sistem in the west region of Paraná state. Revista Brasileira de Fruticultura, Jaboticabal, v. 31, n. 2, p. 447-453, 2009. 
DANTAS, A. C. V. L; QUEIROZ, J. M. O.; VIEIRA, E. L.; ALMEIDA, V. O. Effect of gibberellic acid and the biostimulant stimulate ${ }^{\circledR}$ on the initial growth of tamarind. Revista Brasileira de Fruticultura, Jaboticabal, v. 34, n. 1, p. 8-14, 2012.

DAS, A. K.; PRASAD, B. Effect of plant growth regulators on rooting survival of air layering in litchi. Advanced Research Journal of Crop Improvement, v. 5, n. 2, p. 26-130, 2014. https://doi.org/10.15740/HAS/ARJCI/5.2/126-130

DIAS, J. P. T.; TAKAHASHI, K.; DUARTE FILHO, J.; ONO, E. O. Biostimulant in promoting the sprouting in root cuttings of blackberry. Revista Brasileira de Fruticultura, Jaboticabal, v. 34, n. 1, p. 1-7, 2012.

FAOSTAT. Produção mundial de Figo (Toneladas). http://faostat3.fao.org/faostatgateway/go/to/download/Q/QC/E. 22 Ago. 2017.

FERRAZ, R. A.; SOUZA, J. M. A.; SANTOS, A. M. F.; GONÇALVES, B. H. L.; REIS, L. L.; LEONEL, S. Effects of emergency in biostimulant seedling of passion fruit 'Roxinho of Kenya'. Bioscience Journal, Uberlândia, v. 30, n. 6, p. 1787-1792, 2014.

FERREIRA, D. F. Sisvar: A computer statistical analysis system. Ciência e Agrotecnologia, Lavras, v. 35, n. 6, p. 1039-1042, 2011.

IBGE. Lavoura permanente: quantidade produzida de figo. http://www.ibge.gov.br/cidadesat/index.php. 22 ago. 2017.

SILVA, M. J. R.; BOLFARINI, A. C. B.; RODRIGUES, L. F. O. S.; ONO, E. O.; RODRIGUES, J. D. Seedling formation of watermelon in function of different concentrations and forms of application of mixture of plant regulators. Scientia Plena, Aracaju, v. 10, n. 1, p. 1-9, 2014.

SOUSA, C. M.; BUSQUET, R. N.; VASCONCELLOS, M. A. S.; MIRANDA, R. M. Effects of auxin and misting on the rooting of herbaceous and hardwood cuttings from the fig tree. Revista Ciência Agronômica, Fortaleza, v. 44, n. 2, p. 334-338, 2013. https://doi.org/10.1590/S1806-66902013000200016

SOUZA, A. P.; SILVA, A. C.; LEONEL, S.; SOUZA, M. E.; TANAKA, A. A. Estimates of leaf area of fig tree 'Roxo de Valinhos' using linear dimensions of the leaf blade. Ciência Rural, Santa Maria, v. 44, n. 7, p. 11721179, 2014. https://doi.org/10.1590/0103-8478cr20130699

SOUZA, J. M. A.; LEONEL, S.; REIS, L. L.; FERRAZ, R. A.; GONÇALVES, B. H. L. Biostimulant and substrates on litchi tree propagation by air layering. Comunicata Scientiae, Bom Jesus, v. 7, n. 1, p. 122-128, 2016.

TAIZ, L., ZEIGER, E., MØLlER, I. M., \& MURPHY, A. Plant Physiology. 6. ed. Sunderland: Sinauer Associates, 2017, 858p.

TECCHIO, M. A.; LEONEL, S.; REIS, L. L.; SIMONETTI, L. M.; SILVA, M. J. R. Stimulate in kumquat 'Nagami' seedlings development. Irriga, Botucatu, v. 1, n. 1, p. 97-106, 2015.

TOMAZ, Z. F. P.; SCHUCH, M. W.; PEIL, R. M. N.; TIMM, C. R. F. Plant production of peach tree grafting via active and dormant bud in growing system without soil. Revista Brasileira de Fruticultura, Jaboticabal, v. 36, n. 4, p. 1002-1008, 2014. 